\title{
Migration and Enslavement: A Medieval Model
}

\author{
Youval Rotman
}

At the beginning of the third millennium sociologist Stephen Castles has called for "a sociological argument that points to the significance of forced migration in contemporary society and in current processes of change". ${ }^{1}$ Castles' words have since become a landmark for scholars and activists interested in and working on migration and forced migration. ${ }^{2}$ Five years prior to the publication of Castles' article, the Refugee Participation Network - RPN - newsletter changed its name and format and became the Forced Migration Review. Published since 1998 by the Refugee Studies Centre in the Oxford Department of International Development, University of Oxford, it was launched in order to "contribute to improving policy and practice for people affected by forced migration; provide a forum for the voices of displaced people; be a bridge between research and practice; raise awareness of lesser-known (or little covered) displacement crises; and promote knowledge of, and respect for, legal and quasi-legal instruments relating to refugees, IDPs and stateless people". ${ }^{3}$

Although the $F M R$ preceded Castles article's publication by five years, its foundation can be considered as a response to the same need for a conceptual framework in the study of what has become over the last two decades the largest movement of people today. This is evident in particular in view of the premises that Castles has laid out in connecting forms of forced migration to the new economic system of globalization as well as to the socio-political framework of transnationalism. The large movement of people around the world today, and in particular from South to North, is therefore linked to, and is perceived as a product of the radical socioeconomic and political changes of our time.

1 Castles, "Towards a Sociology of Forced Migration and Social Transformation", $13-34$.

2 O'Connell Davidson, "Troubling freedom: migration, debt, and modern slavery", 1-20: Turton, "Conceptualising forced migration"(https://www.rsc.ox.ac.uk/files/publications/workingpaper-series/wp12-conceptualising-forced-migration-2003.pdf, retrieved on 22/4/2017). See in particular Stepputat/Nyberg Sørensen, "Sociology of Forced Migration".

3 http://www.fmreview.org/index.html, retrieved on 1/5/2017. 
The fact that forced migration is perceived and understood in relation to globalization and transnationalism makes it resemble very much another contemporary global social phenomenon: modern slavery. This term has become prevalent in modern political and human rights discourse in englobing extreme forms of human exploitation, forced labor, human trafficking and human bondage. According to the ILO's 2012 report nearly 21 million people were found victims of forced labor around the world that year: 11.4 million women and girls and 9.5 million men and boys. ${ }^{4} 19$ million victims are exploited by private individuals or enterprises, and over 2 million by states or rebel groups. Of those exploited by individuals or enterprises, 4.5 million are victims of forced sexual exploitation. ${ }^{5}$ Domestic work, agriculture, construction, manufacturing and entertainment are among the sectors most concerned.

In 1999 sociologist and economist Kevin Bales has published a first of its kind monograph: Disposable People: New Slavery in Global Economy. ${ }^{6}$ On over 300 pages divided into seven chapters Bales offers a first-hand analysis of the operations of five slave-based businesses: prostitution in Thailand, selling of water in Mauritania, production of charcoal in Brazil, general agriculture in India, and brickmaking in Pakistan. Bales have analyzed all five cases from an economic and sociologic perspective and revealed them as products of particular social structures and juridical conditions. All cases refer to people who were not illegally enslaved, were not victims of illegal kidnapping or human trafficking, and were not forced to labor against the law. The forms of exploitation used in all cases were legal and did not require change of residency of the exploited persons. They were products of the way the juridical and socioeconomic systems in their particular countries functioned. However, Bales was not satisfied in an overview of such phenomena, but contextualized them in the framework of globalized economy. This context is what makes people disposable, i.e. exploited in slavery-like manner, which severely restricts their freedom. The restriction of freedom of people as a means to exploit, merchandize and profit from their labor is perceived here as a cardinal criterion that constitutes de facto slavery. One of the main elements in the situation of these people as disposable is the restrictions of mobility, their freedom of movement.

4 "ILO Global Estimate of Forced Labour: Results and methodology" (http://www.ilo.org/global/topics/forced-labour/policy-areas/statistics/lang--en/index.html, retrieved on 13/6/2016).

5 Compare to the higher estimates of the "Global Slavery Index" (http://www.globalslaveryindex.org/ retrieved on 13/6/2016), according to which the number of victims of modern slavery is more than twice as high: 45.8 million. The reason for this difference is the fact that the "Global Slavery Index" uses the terminology of slavery in regards to contemporary forms of exploitation much more freely than the ILO. See Rotman, "Comparing Slavery".

6 Bales, Disposable People. 
Whether we call them slaves or not, they are bound to their exploiters by juridical and economic constrains, and are certainly not free to change their position. In fact, the very form of their exploitation depends on this incapacity. A priori, this situation of human bondage is very different from the situation of migrants who are forced to leave their homeland. However, here too the situation and the restrictions that it entails on the individual are dependent on economic and political conditions of the globalized economic system that enables and encourages merchandizing of humans. This economic transnational framework is precisely what turns the conceptualization of such forms of exploitation from human bondage to modern slavery. Both "disposable people" and "displaced people" therefore seem to be victims of a global economic system, which determines their personal condition by limiting their rights of movement. Both those who are prevented from moving and changing their situation, and those who are prevented from staying in their homeland and continuing with their life, are forced into a life of precarious socioeconomic and civil status in which their labor and themselves can be merchandized. We can ask whether the uncertainty in the socioeconomic situation for most people in today's world is not the cause of uncertainties of residency and settlement for both displaced people and disposable people. The question is in what way these two social situations are connected.

The overlapping area between forced migration and modern slavery is recognized and referred to in modern scholarship. In their description of what constitutes forced migration, David A. Martin, T. Alexander Aleinikoff, Hiroshi Motomura and Maryellen Fullerton define the different types of forced migrants. Along with refugees, asylum seekers, internally displaced persons, development-induced displacees, environmental and disaster displaced, smuggled people, we also find trafficked people "who are moved by deception or coercion for the purposes of exploitation. The profit in trafficking people comes not from their movement, but from the sale of their sexual services or labour in the country where they work. The trafficked persons may be physically prevented from leaving, or be bound by debt or threat or violence to themselves or their family in their country of origin". ${ }^{7}$ However, trafficked people are not the only migrants whose civil status and freedom are restricted. The restrictions of freedom and rights of migrant workers have been the subject of recent studies, which emphasized the extreme forms of their social dependency and exploitation. Daromir Rudnyckyj, for example, shows how what he calls "servile status" becomes essential in the training of migrant workers in both

7 Martin/Aleinikoff/Motomura/Fullerton, Forced Migration, pp. 10-11. 
their socioeconomic position in their state of origin and their state of destination. ${ }^{8}$ Even if we do not accept his definition of "servile status" as a socioeconomic condition, we still need to acknowledge the fact that social submission is a significant part of migrant workers' position. Adriana Kemp and Rebeca Raijman have recently showed how state's regulations play a decisive role in establishing private mechanisms of dependency and exploitation. ${ }^{9}$ In both cases, however, the people in question are not forced migrants, but migrant workers who seem to have immigrated out of their "free will". The fact that these workers are foreigners makes it particularly easy to manipulate their juridical situation, since they are not citizens in the society of destination. This however does not entail their definitions as "modern slaves", but it certainly challenges the perception that sees trafficked people as a sub-category of modern slaves in the rapidly growing group of forced migrants today.

More and more scholars propose to examine the relation between slavery and forced migration in different directions other than in cases of human trafficking. Lotte Pelckmans, for example, shows how the institution of slavery still determines patterns of mobility and migration in modern Africa. ${ }^{10}$ The same is also true in regards to the juridical heritage of Atlantic slaveries: Shannon Clancy, for example, has shown how juridical conventions dated to the American slavery institution, still play an important role and condition the way immigrants are treated today. ${ }^{11}$ In fact, the Atlantic slavery is in itself considered as a phenomenon of migration. ${ }^{12}$ Such studies do not intend to change the historical perspective of Atlantic slavery, but to develop along them a new perspective in which slavery will take its place also in the history of migration to the Americas. Such a perspective links together two distinct phenomena of human movement: forced migration and human trafficking through the study of slavery.

The Atlantic slavery is by far best and most appallingly documented phenomenon of forced migration in world's history. Between the 15th and the 19th centuries, over 13 million Africans were forcibly removed from Africa and

$8 \quad$ Rudnyckyj, “Technologies of Servitude”.

9 Kemp/Raijman, "Bringing in State Regulations". About the employer-employee bound see also: Depatie-Pelletier, Judicial Review.

10 Pelckmans, "Dependent Mobility"; cf. Botte, "Les habits neufs de l'esclavage"; Idem, Esclavages et abolitions en terres d'Islam. Idem (ed.), L'ombre portée de l'esclavage.

11 Clancy, "Immigration and Modern Slavery".

12 Magee, "Slavery as Immigration?". 
shipped to the Americas. Of these 11 million reached the Americas. ${ }^{13}$ The objective of the Atlantic slave trade was the exploitation of Africans as slaves. The rationale was economic, and the human trafficking on such a large scale together with forced migration of Africans in and out of Africa, were all means to attain these objectives. Although the Atlantic slave trade is a part of the long and painful history of slavery, it may and should be regarded as exceptional for its scale, documentation and management. ${ }^{14}$ This was above all an appallingly planned and managed economic enterprise targeted at producing a profit from the new world's lands. In this respect, the Atlantic slaveries were all ex-nihilo creations. They served one global economic agenda for which slavery, human trafficking and forced migration proved to be complementary means. If we compare this to today's phenomena of modern slavery and forced migration, we will have difficulties to identify an intentionally-programmed economic framework at their basis. This is also the reason why scholars are struggling to find a coherent definition and common criteria that will enable to link together different and a-priori unrelated phenomena of human exploitation..$^{15}$ In addition, this is also, why Castles' article from 2003 is still very much relevant. The main questions that scholars of forced migration are concerned with are therefore: first, what could be the main argument that points to the significance of forced migration? And second, in what way is this related to the question of slavery?

I propose to address these questions by focusing on another period of history in which they played an important role: the Byzantine medieval world. Slavery, human trafficking and forced migration have proved to be significant in sustaining and maintaining a transnational economic and political system in that period. In what follows, I would like to examine how.

\section{Slavery in a Medieval World}

The institution of slavery is considered in modern scholarship as an integral part of the economic and social life of the Roman Empire, a part that played a

\footnotetext{
13 Eltis, The Rise of Slavery.

14 See Pétré-Grenouilleau, Les traits négrières, who has shown that this was a part of a much bigger global forced movement of Africans to the Mediterranean and the Indian Ocean as well as within the African continent. Cf. Lovejoy, Transformations in Slavery. Quirk/Vigenswaran, Slavery, Migration and Contemporary Bondage in Africa.
} 
decisive role in the Roman and late Roman economic expansion..$^{16}$ Although the late Roman world has known several crises in the $5^{\text {th }}-7$ th centuries, slavery did not disappear from the regions of the Roman Empire, nor do we have evidence for its decline. On the contrary, recent studies have revealed it as an integral part of early medieval societies, especially in the Mediterranean regions of the Roman Empire. ${ }^{17}$ Whether in Gothic Italy, Carolingian Europe, Byzantium or the Caliphates, slavery continued to play a role in the social life despite other coexisting forms of social dependency. Continuity and change characterize the different juridical definitions of slavery and its social conditions in all these medieval societies, successors of the Roman civilization. These definitions developed out of more ancient (Roman and non-Roman) juridical definitions of ownership of human beings. In Byzantium, in particular the juridical institution of slavery was a direct offshoot of Roman slavery and continued to concern, and extensively, the imperial legislator. ${ }^{18}$ Whether we can refer to a common institution of "medieval slavery" is a question, which depends on our perspective. ${ }^{19}$ In what follows, I would like to reconstruct a common context for such a discussion, in which the different institutions of slavery in the medieval world can be connected. Their nexus will prove to be forced migration on a transnational scale.

Enslavement occurs from birth or later in life. A person can be enslaved by force, or even sell himself or his children into slavery. The Roman authority of a juridical personhood included the freedom over the person's life and death, and the authority of the pater familias included the life and death of his children..$^{20}$ In late antiquity, however, this authority of a person over his and his children's lives was severely restricted. ${ }^{21}$ Imperial legislation tried more and more to fight the phenomenon of parents exposing and selling their children as well as the act of selling oneself, and allowed it only in cases of severe

16 Andreau/Descat, The Slave in Greece and Rome; Bradley, Slavery and Society at Rome: Harper, Slavery in the late Roman World.

17 Glancy, Slavery in Early Christianity: Rotman, Byzantine Slavery; Rio, Slavery After Rome; Rio, "Freedom and Unfreedom"; MacMaster, Slavery in the Early Middle Ages; Rāgib, Actes de vente d'esclaves; Gordon, Slavery in the Arab World; McCormick, Origins of the European Economy, pp. 733-777. Perry, The Daily Life of Slaves. But see for a different view Harper, Slavery in the Late Roman World.

18 Rotman, Byzantine Slavery, pp. 189-195.

19 Rotman, "Forms of Slavery".

20 Ville "Selling a Freeborn Child"; Harper, Slavery in the late Roman World, pp. 391-423: Westbrook, "Vitae Necisque Potestas"; Thomas, "Vitae necisque potestas. Le père, la cité, la mort".

21 Codex Justinianus, ed. Krüger, p. 179 (IV.43 dated to 294), forbade such an act. Melluso, $L a$ schiavitù nell'età giustinianean, p. 33 and following; Harper, Slavery in the Late Roman World, p. 392 and following. 
economic crises and natural calamities. ${ }^{22}$ The act of selling oneself was abolished by Leo VI. ${ }^{23}$

Slavery by birth, however, was another matter. This was prevalent in GrecoRoman societies, and present also in Byzantium, the Caliphate and Latin Europe. In Byzantium, a house-born slave was known as oikogenēs, just like in antiquity. However, while this term is frequent in Greco-Roman sources, it becomes rare in Byzantine sources. ${ }^{24}$ One way to look at it would be to see this as a sign of decline in the use of slaves in Byzantine society. However, an analysis of testaments of Byzantine slaves owners from Asia Minor, Egypt, Greece and Southern Italy shows that it was a common custom to free the slaves, including the house-born, in order to introduce them as socioeconomic dependent freedman. ${ }^{25}$ This is also evident from the attention payed by the Byzantine legislator to marriage of Christian slaves and the way in which it affected their status, as well as to marriages of mixed status between freemen and slaves. ${ }^{26}$ Freedmen were not free to go their own way, but were dependent on their former owner's family. As we shall see below this dependency worked in both ways, since the household's economic preservation and expansion in both Byzantium and the Caliphate depended on the ability to integrate dependent persons as household members

In contrast to the clear-cut juridical demarcation between slave and free person in Byzantium and the Caliphate, the laws and juridical records of the Latin West suggest an amalgam of statuses of social dependency of peasants that also included slaves. Carolingian capitularies which were analyzed by Alice Rio reveal the blurred line between status of slaves and dependent peasants through the ambiguous meaning that the Latin terms servus, servitium, servitus (originally "slave", and "slavery" in Roman Latin) acquired in the early medieval period. ${ }^{27}$ This corresponded with the fact that these statuses became mixed

22 Codex Theodosianu, ed. Mommsen, pp. 182-183 (Iv.8.6 dated to 323); Leges Novellae ad Theodosianum, ed. Meyer, pp. 138-140 (Novellae Valientinaini number 33); Holman The Hungry Are Dying, p. 69 (n. 23). For the juridical aspect see: Buckland, The Roman Law of Slavery, pp. 420-422; Kaser, Das römische Privatrecht, p. 6o. On the practice in late antiquity see: Basilii Magni, "Homilia II: In Psalmum XIv", PG 29:277; Glancy, Slavery in Early Christianity, p. 71.

23 Les Novelles de Léon le Sage, eds. Noailles/Dain, no. 59.

24 Rotman, Byzantine Slavery, pp. 184-186. Les Novelles de Léon le Sage, eds. Noailles/Dain, no. 59 .

25 See Lemerle, "Le Testament d'Eustathios Boïlas"; Robinson, Cartulary of the Greek Monastery, pp. 150-157 (doc. IV-53), 179-184 (doc. X-59), 190-194 (doc. XII-61); Rotman, Byzantine Slavery, pp. 123-128.

26 Die Novellen des Kaiserin Eirene, ed. Burgmann, p. 26. Les Novelles de Léon le Sage, eds. Noailles/Dain, nos. 100-101. Novellae et Aureae Bullae imperatorum post Justinianum, coll. iv, nov. 35 in Zepos, Jus Graecoromanum, vol. 1, pp. 401-407; Rotman, Byzantine Slavery, pp. 141-143.

Rio, "Freedom and Unfreedom in Early Medieval Francia". 
through marriage, and reflected the absence of a clear juridical borderline between free and unfree. Slavery in the early medieval West seems to be dependent on hereditary status in contrast to the medieval East and South. These differences in the socioeconomic and juridical statuses of slaves in medieval societies corresponded with different socioeconomic structures of the private household, but it also affected and was affected by the transnational dynamics of medieval slavery.

\section{The Transnational Nexus of Medieval Human Trafficking}

In contrast to slave breading and the selling of oneself or one's children into slavery, the two other sources of slaves, namely war and commerce are omnipresent in Greek, Latin, Arabic and Church Slavonic sources. ${ }^{28}$ War had been a major generator of slavery in ancient times, and continued to be prevalent in late antiquity. While in Roman antiquity continuous internal wars, revolts and strives supplied captives to the Roman slave market, as well as convicts reduced to slavery (servi poenae), the medieval captives were mainly foreigners. ${ }^{29}$

The geopolitical map of the Romano-Byzantine Empire was radically transformed in the $7^{\text {th }}$ century with the loss to the Umayyad Caliphate of all of the Byzantine provinces in Asia and Africa (Palestine, Syria, Egypt, Mesopotamia and North Africa) except from Asia Minor. The continuous wars between Byzantium and the Caliphate affected the entire geopolitical constellation of the Eastern Mediterranean up until the arrival of the Crusades. Thanks to the exchanges of prisoners of war between the two states, the wars between Byzantium and the Caliphate did not become a major source of slaves to either side. $^{30}$ The introduction of this new international custom affected greatly the slave trade since prisoners of war were not sold automatically into slavery, but were held by the state in order to be used in a prospective exchange of captives. ${ }^{31}$ In addition, a new Mediterranean market developed in the central

28 See $n .17$ above.

29 Burdon, "Slavery as Punishment".

3o Campagnolo-Pothitou, "Les échanges de prisonniers"; Kolia-Dermitzaki, "Some Remarks on the Fate of Prisoners"; Rotman, "Byzance face à l'Islam arabe viı--Xe siècles".

31 Leges militares (version B), Ch. 48, ed. Korzenszky, in Zepos, Jus Graecoromanum, vol. 2, p. 89. Note that Leo vi's Tactica specifies that captives can be sold as slaves. In case of a prospective exchange of prisoners, the captives should be kept for such a use: The Taktika of Leo VI, ed. Dennis, pp. 384-386 (const. 16.8-9). For the same in the Balkans see Beševliev, Die protobulgarischen Inschriften, p. 190 (no. 41). Two famous Muslim captives held in 
Middle Ages for the ransoming of captives, and raids and kidnapping on civil population became prevalent. ${ }^{32}$ This had major consequences on the international trade, which, in contrast to antiquity, became the major means to supply the demand for slaves in both Byzantium and the Caliphate. ${ }^{33}$ The slave markets in the major cities of the Caliphate and Byzantium are well attested, ${ }^{34}$ as well as the circulation of slaves into and within the empire. ${ }^{35}$

Medieval descriptions of historians, geographers, voyagers as well as correspondences, fiscal and political treaties, along with archaeological findings, complete the picture and give substantial evidence for the large forced movement of people as slaves to the Muslim world from Africa, the Eurasia Steppe and the Caucasus. The slave trade from the Caucasus to the late Roman Empire is documented for the 4th and 6th centuries. ${ }^{36}$ However, it is only in the 9th century when we begin to have evidence on far-reaching transnational scale of human trafficking that connected the different medieval economies.

In his book The Origins of the European Economy: Communications and Commerce, A.D. 300-90o, Michael McCormick attributed a cardinal role to the international slave market as a key element in the transfer of goods, people and money between the North and the South Mediterranean littorals. In these commercial dynamics, Eastern Europe proved to be a major source of slaves for Mediterranean societies, and for Byzantium and the Caliphate in particular.

Constantinople are Hārūn ibn Yahyyā and Abū Firās al-Ḥamdānī who write his poems, al-Rūmiyyāt in the Byzantine prison: Le Diwan d'Abū Firās al-Hamdānī, ed. Sami Dahan. See Simeonova, "In the Depths of Tenth-Century Byzantine Ceremonial".

32 Rotman, "Captif ou esclave ? La compétition pour le marché d'esclaves en Méditerrané médiévale".

33 Vasiliev, Byzance et les Arabes, p. 201. See also Canard, "Les sources arabes de l'histoire byzantine"; Rāgīb, "Les esclaves publics aux premiers siècles de l'Islam".

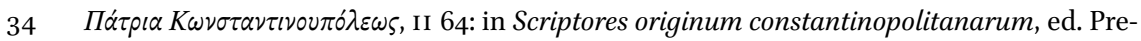
ger, p. 185. Al-Tabarī Tarikh al-rusul wal-muluk, ed. de Goeje, 3:1353 narrates how in 845 the number of Byzantine captives held by the Caliphate was inferior to the number of Muslim prisoners offered for ransom by Byzantium. The caliph al-Wāthiq ordered the purchase of Byzantine slaves in Baghdad and Raqqa in order to have the right number or people to ransom the Muslims captives.

35 Theophanes, Chronographia, ed. De Boor, vol. 1, pp. 486-487. Rotman, Byzantine Slavery and the Mediterranean World, pp. 68-70.

$3^{6}$ The Caucasus was a source of importation of castrated boys: Ammian, XVI, 7, 4-6. Claud., In Eutropium, I, $98 \mathrm{ff} ; 230 f f ; 335$. Procopius Caesariensis, De bello Persico, ed. Haury, Leipzig 1962, Ch. 15. For the Southern late antique slave trade see: Cosmas Indicopleustes, Topographie chrétienne, ed. Wolska-Conus, II.29-30. Seals discovered in seven Byzantine provinces of Asia Minor and dated to the end of the 7 th century, attest to a major sale of Slavic slaves (andrapoda sklabōn) conducted by George the Kommerkiarios under Justinian II: Bendall, "Slaves or Soldiers"; Oikonomides, "Silk Trade and Production in Byzantium"; Hendy, Studies in the Byzantine Monetary Economy, pp. 630-634. 
The competition between these two markets and the way in which it affected and was affected by international politics was a subject of another recent study, which examined the slave trade within the large political context of Byzantium as revealed in its international treaties. ${ }^{37}$ The international medieval slave trade proves to be a decisive factor in the economic and foreign policy of Byzantium. In fact, much more than in antiquity and late antiquity, the medieval sources and documents reveal an international human trafficking in the medieval Eurasia context. The movement of people, which was the result of this economic-political dynamics, was not yet studied as a transnational forced migration. If the medieval international slave trade had an economic-political rationale, the question still remains how it affected the people who found themselves uprooted and trafficked in order to fill in the demand for human merchandize in the South. In order to examine them as forced migrants we should examine who were they, the routes in which they were trafficked, the conditions and means of their uprooting, and the question of their integration into the societies which imported them. If we keep the Atlantic slave trade as a point of comparison, although exceptional for its scale, documentation and management, we can nevertheless investigate the conditions that make forced transnational migration and slavery a single phenomenon in other periods and societies.

\section{3}

\section{The Routes and the People}

Our earliest medieval source of a transnational human trafficking is the Persian geographer Ibn Khurradādhbih (c. 820-912). In his Kitāb al-Masālik wa'-mamälik - the book of itineraries and kingdoms - from the mid-gth century he gives a detailed description of al-Rādhāniyya. ${ }^{38}$ These were Jewish merchants who traded in arms, pearls, fabrics, furs, spices and young slaves of both sexes (Arabic: djawārī, ghilmān), among them eunuchs (Arabic: khadam). The description of Ibn Khurradādhbih has been the subject of much scholarship. ${ }^{39}$

37 Rotman, "Byzantium and the International Slave Trade".

38 Ibn Khordādhbeh, Kitāb al-Masālik wa'l-mamālik, ed. de Goeje, p. 153 (129) and following.

39 Assaf, "Slavery and the Slave-Trade among the Jews during the Middle Ages (from the Jewish sources)"; Gil, "The Radhanite Merchants and the Land of Radhan"; Ashtor, "Aperçus sur les Radhanites"; Idem, "Gli Ebrei nel commercio mediterraneo nell'alto medioevo"; Gieysztor, "Les juifs et leurs activités économiques en Europe orientale"; Verlinden, "Les Radaniya: Intermédiaires commerciaux entre les mondes Germano-Slave et GrécoArabe"; McCormick, Origins of the European Economy, pp. 688-695; Holo, Byzantine Jewry in the Mediterranean Economy, pp. 9294; Kulik, "Jews and the Language of Eastern Slavs". 
The historians who dealt with it have tried to contextualize the Radhaniyya in the framework of the Jewish trafficking in slaves in the central Middle Ages, while others have questioned their very existence..$^{40}$ Ibn Khurradādhbih describes four itineraries, across lands, seas and rivers: ${ }^{41}(1)$ The first itinerary led the Radhaniyya from Firandja, across the Mediterranean to the Red Sea, and on to Sind, India and China, from where they imported spices. (2) The second itinerary started also from Firandja, and led them to Sind, India and China, but this time through Antioch, the Euphrates, Baghdad and the Persian Gulf. (3) The third itinerary was a land route that passed through North Africa to Egypt, Palestine, Syria and Iraq. (4) The fourth itinerary led them through the land of the Slavs (al-sakāliba), and across the Khazar kingdom and the Caspian Sea to Transoxiana. This fourth itinerary of human trafficking joins the account of Ibn Fadlān of his 1oth-century expedition to the Bulgars of the Volga, here with no relation at all to the Radhaniyya (or any other Jewish merchants for that matter). ${ }^{42}$ Other sources, of European origin, give more information about the trans-European itineraries that connected to those described by Ibn Khurradādhbih, such as the tolls on the Danube at Raffelstätten, the itineraries on the Rhône, and in Italy. All these European itineraries ran from Northeast to South-West. ${ }^{43}$ Fluvial and maritime routes in Eastern Europe, the Balkans and the Black Sea, were all used to lead local inhabitants to the Byzantine markets, which were regulated from Constantinople. ${ }^{44}$ I have argued elsewhere for a competition between the Byzantine and the Caliphal markets that conditioned the itineraries of the traffickers, and showed how it led Byzantium to construct an international policy around the concessions given to foreign slave traders. ${ }^{45}$ I would like to focus here on the very nature of this human merchandize. Who were these people, and whether we can indeed refer to them as forced migrants?

The sources of the North-South itineraries described above were Eastern Europe and the Caucasus. Indeed Bulgars, Rus'/Varangians and Khazar merchants played a cardinal role in connecting this source to the trans-European

$40 \quad$ See Cahen, "Y a-t-il eu des Radhanites ?"; Toch, The Economic History of European Jews, pp. 196-200.

41 Eng. trans. Charles Pellat, "al-Rādhāniyya".

42 Ibn Fadlān, trans. Canard, p. 71 and following.

43 McCormick, Origins of the European Economy, pp. 553-557. For a map of these itineraries see: Rotman, Byzantine Slavery, pp. 6o-61; https://networks.h-net.org/medieval-humantrafficking-map-and-data-dr-youval-rotman (retrieved on 19/1/2020).

44 Rotman, Byzantine Slavery..., op. cit., pp. 68-76. Ferluga, "Der byzantinische Handel auf der Balkanhalbinsel vom vir. bis zum Anfang des XIII. Jahrhunderts".

Rotman, "Byzantium and the International Slave Trade". 
itineraries leading to the Mediterranean and Near Eastern markets. ${ }^{46}$ The fact that Eastern Europe became such a major source for slaves corresponds with the terminology of slavery. In Byzantium the term "Slav" (Greek: sklavos), joined another Greek term, "Scythian" (Greek: skuthēs) to designate the origin of the slaves referring to a geopolitical origin: Eastern Europe and the Caucasus. ${ }^{47}$ This is also the case as far as the Arabic sources are concerned which refer to sakăliba as the local population of these regions. Ibn Fadlān use it to designate the Bulgar of the Volga, Ibn Khurradādhbih notes that the Rus' are a specie (djins) of sakäliba, while in al-Andalus the same term designated European/White slaves. ${ }^{48}$ Modern scholarship no longer refers to the sakâliba exclusively as Slavs, but also includes in it Scandinavians and Finno-Ugrians along with various population of Eastern-Northern Europe, mainly based on the sakāliba's customs as described by the Arabic Geographers. ${ }^{49}$ As McCormick has shown, the circulation of human merchandise was conditioned also by the fact that the peoples of central and Eastern Europe did not mint coins before the 1oth century. ${ }^{0}$ This explains the demand of these regions for Byzantine, Arab and Samanid gold coins, which were found in the north, up to the Baltic Sea, and to the east, up to the Oka River, a tributary of the Volga. ${ }^{51}$ These lands figure as important medieval sources for slaves. ${ }^{52}$

46 McCormick, Origins of the European Economy, pp. 738-754; Sorlin, "Voies commerciales, villes et peuplement", in particular pp. 338-339. Rotman, Byzantine Slavery, p. 71.

47 Köpstein, "Zum Bedeutungswandel von sclavus"; Kahane/Kahane, "Notes on the linguistic history of 'sclavus"; Patlagean, "Nommer les Russes en Grec, 1081-1294"; Rotman, Byzantine Slavery, p. 187.

48 Ibn Fadlān; Ibn Khordādhbeh, Kitāa, p. 154; Guichard/Meouak, "al-Ṣakāliba", 872-881.

49 Watson, "Ibn al-Athīr's Accounts of the Rūs: A Commentary and Translation".

5o McCormick, Origins of the European Economy, pp. 343-384.

$5^{1}$ See Kazanski, Nercessian, Zuckerman, Les Centres proto-urbains russes, and especially the following: Nosov, "Rjurikovo, Gorodišce et Novgorod", pp. 148, 152; Sedyh, "Timerevo - un centre proto-urbain sur la grande voie de la Volga", pp. 175-178; Puškina, "Les trouvailles monétaires de Gnezdovo: un marqueur des relations commerciales", pp. 215-224; Ivakin, "Kiev aux VIII ${ }^{\mathrm{e}}-\mathrm{X}^{\mathrm{e}}$ siècles", pp. 231-232; Noonan, "The Impact of the Islamic Trade upon Urbanization in the Rus' Lands: the Tenth and the Early Eleventh Centuries", pp. 379-393; Esperonnier, "Les échanges commerciaux entre le monde musulman et les pays slaves d'après les sources musulmanes médiévales".

52 Rotman, "Byzantium and the International Slave Trade"; Sorlin, "Voies commerciales"; Sorlin, "Les Traités de Byzance avec la Russie au $\mathrm{x}^{\mathrm{e}}$ siècle"; The Russian Primary Chronicle, ed. Hazzard Cross/Sherbowitz-Wetzor, pp. 68, 75, 86. 
What did this human trafficking look like is difficult to assert. In his description of the people of Eastern Europe, Ibn Rustah mentions twice the Sakāliba as a source of slaves. Both the Rus' and the Madjghariyya ("Magyars") raid them, traffic them and sell them as slaves, the first in Khazran (Khazar land) and Bulkar (Bulgar land), and the second in Kerch on the way to Byzantium. ${ }^{53}$ We can maybe extrapolate from such descriptions as well as from hoards of foreign gold coins that local population was kidnapped and trafficked by slave traders and sold out to traders by local chiefs. ${ }^{4}$ Such raids were also practiced in the Balkans on passengers traveling on both land and river. ${ }^{55}$ Indeed iron chains and shackles used by slave traders were found in Eastern Europe. ${ }^{56}$ Byzantium and the Rus' paid special attention to put in their treaties clauses to protect themselves from being the victims of such slave traders by mutual agreements to ransom each other if found on the slave market. ${ }^{57}$ These measures did not weaken the use of slaves, but they did orient these societies to look for other sources for slaves. Particularly prevalent in the Eastern Mediterranean was piracy.

Piracy is a very effective way for procuring slaves. This was, of course, not a new Mediterranean phenomenon. However, it put on a new form during the central medieval period in the Eastern Mediterranean regions. It became mostly disturbing for the Byzantine population starting from 826 when an Arab force occupied the island of Crete. Until 961-963 when Nikephoros II Phokas regained it, it was used as a basis for maritime raids on littoral Byzantine population. ${ }^{58}$ The target was not a military victory, but the Byzantine population itself which was kidnapped, enslaved and then sold in Arab markets.59 This was also the strategy of the Arab infantry in Asia Minor - raids into Byzantine hinterland that resulted in selling the local population. Two famous

53 Ibn Rosteh, Kitāb al-A'lāk an-Nafīsa vII, ed. de Goeje, pp. 142-145.

54 See $n .51$ above.

55 Vita Blasii Amoriensis in AAss Nov. 4, pp. 657-659. Zhitie Nauma in Kirillo-metodiesvskoj, ed. Florja/Tarilov/Ivanon, pp. 286-288.

56 Henning, "Gefangenfesseln im slavischen Siedlungsraum"; McCormick, Origins of the European Economy, pp. 741-752; Sophoulis, Byzantium and Bulgaria, p. 181, n. 58, who cites Nicolaus capitulis 106 ad Bulgarorum consulta respondet, in MG H, Epp. VI, Epist. Karolini Aevi IV, pars. II, fasc. 1, pp. 568-60o.

57 The Russian Primary Chronicle, p. 68; 75. Sorlin, "Les Traités de Byzance avec la Russie au xe siècle", pp. 458-459.

$5^{8}$ Christides, The conquest of Crete, pp. 81-83.

59 Rotman, Byzantine Slavery, pp. 47-56. 
examples are the sack of the city of Heraclea in Asia Minor in 802/3 or 806 and of Thessalonica in 904. ${ }^{60}$ Arab piracy threatened the Greek islands, Sicily, Southern Italy, the Peloponnese and the littoral of Greece and Asia Minor. ${ }^{61}$ The Byzantine strategic response in those regions was sometimes the evacuation of the local population. ${ }^{62}$ The Byzantines, however, were not only victims, but also exerted military attacks in order to procure slaves. ${ }^{63} \mathrm{In}$ fact, this was a common practice in both the Mediterranean and Eastern Europe. Behind this dynamics we find a combination of two conditions: the dependence of the medieval socioeconomic expansion on slavery (see infra), and the fact that the Mediterranean markets depended on importation of foreign slaves. A decisive factor was the role religion played in the definition of who was considered as an outsider, a foreigner, and could be legitimately enslaved.

\section{$5 \quad$ Foreign Forced Migrants}

The new political definition of the state as a religious community in both the Caliphate and Byzantium affected the definition of the borderline between slave and free person. Medieval laws defined the free status of members of their respective religious communities as a permanent "civil status". This meant that a free Muslim, for example, could not lose his de jure status as a free person within the Caliphate, and likewise for a free Christian in Byzantium. ${ }^{64}$ The religious identification that maintained the free status of the member of a religious community left the enslavement of foreigners as the only source of slaves and provided the rationale for a transnational forced migration. This constituted raids and piracy as popular means of human trafficking. Prohibitions on selling co-religionists to slave traders and international conventions on redeeming co-religionists were aimed at limiting commercial trafficking in

6 Canard, "La prise d'Héraclée". John Cameniates, De expugnatione Thessalonicae, ed. Böhlig. Vasiliev, Byzance et les Arabes, vol. 2/1, pp. 166-168; Christides, The conquest of Crete, pp. 159-161.

61 Hagios Nikolaos, ed. Anrich, pp. 151-197 (Methodii Economium, Ch. 42-43, Thaumata tria Ch. 8ff). Les Récits édifiants de Paul, ed. John Wortley, Paris 1987, Ch. 8. Vita di Sant'Elia il giovane, ed. Rossi Taibbi.

62 The Life and Miracles of Saint Luke of Steiris, eds. Connor/Connor. Vita S. Theoctistae, in AASS Nov. 4 pp. 224-233. Vie de sainte Athanasie d'Égine, in Halkin, Six inédits d'hagiographie byzantine, pp. 179-181.

63 Ibn Ḥāwkal, Kitāb Sūrat al-ard, ed. de Goeje, p. 205. AASs Nov. 4, pp. 46-48.

64 Rotman, Byzantine Slavery, Ch. 2. 
local inhabitants, but left of course open the importation of infidel foreigners, i.e. religious outsiders, as slaves. In fact, these were two sides of the same phenomenon of medieval slavery. This is evident from the attempts of Christian rulers and writers to limit the trade in Christians. ${ }^{65}$ The main problem that they faced was the fact that Christians sold Christians to non-Christian slave traders. The Byzantine legislator tried to fight this by asserting the freedom of Christian Bulgars kidnapped and traded into Byzantium. ${ }^{66}$ Although these measures to fight the trade in Christians were not always successful, they created a special rationale for the transnational slave trade, which favored importation of pagans. ${ }^{67}$ The major sources of slavery in the central Middle Ages were the Slavic and Bulgar population and the people from the steppe. For the Caliphate's markets, Africans from the Sub-Sahara completed the demand for non-Muslim slaves.

Importation is a maybe a too sterile term to designate the fact that what the human merchandize itself experienced was the violence of abduction, forced migration, and enslavement. These people were kidnapped either from their homes or on their way, and were sold to slave traders who led them in transnational roads. ${ }^{68}$ This was precisely what gave raids and piracy the importance it held in the Middle Age as a form of human trafficking that connected the Balkans, Eastern Europe, the Caucasus and Eurasia steppe in a global commercial nexus. The only objective was to sell these people for their remunerating value far away from their home country. Some could be indeed ransomed by their family. However, unlike the victims of the early Modern corsairs, the ransom of the kidnapped population in the medieval Mediterranean, except from cases of very notorious captives, was never more than the price of a slave. The ransom market was completely dependent on the slave market. ${ }^{69}$

65 Agobardi Lugdunensis Opera omnia, ed. van Acker, pp. 189-195 (no. 11). MG H SRG, Epistolae, vol. 8. Codex Carolinus, pp. 584-585 (no. 59). Tafel/Thomas, Urkunden vol.1, p. 3 (no. 3); 5 (no. 7 ).

66 See, $\mathrm{n}$. 70 below.

67 For the repetitions of these measures in the later period see Pahlitzsch, "Slavery and the Slave Trade in Byzantium in the Palaeologan Period", who nevertheless stressed that these measures were not successful since Byzantines still participated in the transnational slave trade of Christians.

68 See $\mathrm{n} . \mathrm{5}^{2}$ and n. 53 above.

69 Cf. Kaiser, Le Commerce des Captifs; idem, Friction profitable. Fontenay, "L'esclavage en Méditerranée occidentale au XVII ${ }^{\mathrm{e}}$ siècle"; Idem, "Corsaires de la foi ou rentiers du sol ? Les chevaliers de Malte dans le ${ }^{\circ}{ }^{\circ}{ }^{\circ}\left({ }^{\circ} 0^{\circ} »\right.$ méditerranéen au XVII ${ }^{e}$ siècle". 
The fact that both Christians and Muslims were restricted in the trafficking of their co-religionists, oriented the slave traders and pirates to look for victims among their religious rivals and the pagans. If Christians, Muslim and Jews established networks to ransom their coreligionists, this was not the case in regards to the pagan population. The process of the Christianization of Eastern Europe oriented the slave trade further and further away to the East, and the same rationale conditioned the sub-Sahara's slave trade. The Novella of Alexius Komnenos from 1095 is a perfect example of the way Bulgars could no longer be enslaved in Byzantine raids when considered free born and Christians. ${ }^{70}$ The same also applied to the Rus' once they became Christians, as is stipulated in the treaties that they signed with Byzantium. ${ }^{71}$ This is how the demand for slaves and the conditions of whoever could be enslaved were linked and determined forced migration from outside the realm of Christianity to Byzantium, and outside the realm of Islam to the Caliphate. The question is what happened to these forced migrants once trafficked, enslaved and sold in Mediterranean societies. How were the enslaved migrants treated and were they integrated?

\section{6 The Question of Integration}

The two famous anthropological theories about integration of slaves in African societies proposed to look at slavery as a means of social integration of foreigners on the continuum of kinship (Suzanna Miers and Igor Kopytoff), or as a means to obtain powerin opposition to system of kinship (ClaudeMeillasoux). ${ }^{72}$ If we ignore the insistence on a single sociological model to explain the existence of slavery, we can acknowledge instead that medieval societies imported slaves to serve a variety of socioeconomic roles, and that the main importance of slavery was this variety.

Whether slaves continued to be used in agriculture is a matter of debate, and depends on the interpretation of the medieval evidence. The Zanj were bands of enslaved Africans imported by the Abbasids to Iraq, which found an

70 Zepos, Jus Graecoromanum, vol. 1, pp. 401-407. In this period the Bulgars are Christians. The second part of the same Novella concerns Christian marriage of slaves, and can indicates to the fact that the enslaved Bulgars were considered as Christians. See Köpstein, "Zur Novelle des Alexios Komnenos".

71 Sorlin, "Les Traités... de Byzance avec la Russie au xe siècle", pp. 313-36o; 447-475 (pp. 458-459).

72 Miers/Kopytoff, Slavery in Africa; Meillasoux, Anthropologie de l'esclavage. 
opportunity to escape the miserable conditions in which they were put, preparing the marshy ground of lower Mesopotamia for cultivation. Their revolts (689-69o, 694, 869-883) under the leadership of Ali ben Muhammad are welldocumented thanks to the historian al-Tabarī. ${ }^{73}$ This is a unique case of substantial evidence surviving on the role that imported enslaved Africans played in Abbasid agriculture. ${ }^{74}$ The evidence from Byzantium and the Latin west for the same period, though scanty, points clearly to the rural use of slaves in these regions, always alongside peasants of free status: dependent tenants, landowners, or hired workers. ${ }^{75}$

In urban manufacture, the use of slaves as agents and guild members raised the socio-economic position of the household. The Book of the Prefect of the 1oth century clearly reveals the special role that slaves played in the urban economy as agents of economic expansion thanks to their special juridical status. ${ }^{76}$ Genizah documents from the 11th-12th centuries attest to a similar use of slaves as agents by Jewish traders. ${ }^{77}$ The special status of the slave offered a reliable agent whose personal condition depended on his financial success as a family household member. The fact that slaves were foreigners and had no possible social and economic ties other than in their new household only increased this dependency. Sunni law gave sons the status of their fathers and made it particularly useful for a male slave owner to enlarge his household through the sons of his female slaves. ${ }^{78}$ Polygamy and multi-concubinage, both customary in Muslim societies, proved advantageous for the expansion of the household especially under the Abbasids. ${ }^{79}$ In such ways slavery served as a means of expansion of the family and the family socioeconomic unit. In Byzantium, the term "my people" (hoi anthrōpoi mou) became a mark of social status and comprised all male persons under the influence of a single master. ${ }^{80}$ Manumission perpetuated the social dependency of both slaves and their

73 The History of al-Tabari Vol. 36 , trans. Waines. For the slave trade from East Africa see: Martin, "Medieval East Africa".

74 See Franz, "Slavery in Islam: Legal Norms and Social Practice". See Gordon, "Preliminary remarks on slaves and slave labor".

75 Rotman, Byzantine Slavery, pp. 107-120. Rotman, “Formes de la non-liberté". Rio, Slavery After Roman, op. cit.

76 Rotman, Byzantine Slavery, pp. 95-102.

77 Goitein, A Mediterranean Society, vol. 1, pp. 130-133; vol. 3, pp. 330-332. Idem, "Slaves and Slave girls". Idem, Friedman, India traders of the middle ages, pp. 454-456.

78 Brunschvig, " 'Abd", 1:27. Gordon, Slavery in the Arab World, pp. 46-48.

79 Gordon, "Unhappy Offspring?".

$80 \quad$ Rotman, Byzantine Slavery, pp. 105-107. 
descendants within the family, while integrating them into the socio-economic structure of the household at all social levels. ${ }^{81} \mathrm{~A}$ different aspect of this was the use of slaves and freedmen in both Byzantine and Arab societies in militia forces and as bodyguards in both private and public sectors. ${ }^{82}$ Sakăliba slaves were used and even formed the Fatimid administration. ${ }^{83}$ In any of their destinations these foreigners were converted by their owners as a form of both submission and integration. In fact, there was no difference between the two: integration was attained through submission and vice versa.

The most characteristic example of the versatile nature of medieval slavery is to be found in the military function of slaves in the Arab world. The Mamluks, literally the "owned", were imported as boys from the Eurasian steppe and the Caucasus to form the military elite of the Muslim political leaders. Known as brave, they were trained in special military schools, converted to Islam, and manumitted. They could marry, but could not pass on their position to their sons. The entire institution of the Mamluks was based on the perpetual importation of enslaved boys, often of Turkish origin from Northeast, detached from their family and country, in order to generate the continuation of this military elite institution. Undoubtedly this use of forced migrant foreigners to form particular parts of the elite in medieval societies, was marginal in comparison to other destines in which trafficked human beings found themselves. This was a very different destiny than the one of the Zanj, to take one example. The Mamluks and the Zanj had nothing in common except for the fact that both were enslaved forced migrants. In particular the first were emancipated while the second were not. This reveals the main importance of slavery in this period: it could be employed in extremely varied ways precisely because the enslaved were forced migrants. Both Miers' and Kopytoff's model from the one hand, and Meillasoux's model on the other hand, were employed by the same society. In Byzantium, too, slaves were used on a continuum with kinship to enlarge the private household and its financial situation as freedmen. But, they were also used to enlarge the power of the household owner in opposition to kinship. Both uses were not contradictory, and depended on a common condition: these human beings were owned foreigners. Only forced migration ensured this condition.

\footnotetext{
81 Rotman, Byzantine Slavery, pp. 123-128. Franz, "Slavery in Islam".

82 Franz, "Slavery in Islam"; Peira, 42.17. Cecaumeno, Raccomandazioni e consigli di un galantuomo, ; Zepos, Jus Graecoromanum, vol. 1, pp. 401-407.

83 Jiwa, "From Slaves to Supporters"; Ayalon, Islam and the abode of war.
} 
It is impossible to estimate the numbers of men, women and children who were enslaved, trafficked and forced to a life away from their country, people and family in the Middle Ages. Unlike the Atlantic slave trade, we have little concrete numerical evidence before the early modern period. However, societies which had the means to acquire foreigners, did so, and on a large scale, primarily to use these people in different economic forms and social strata. Indeed, forced migration and slavery prove to be in the Middle Ages two sides of the same coin. Slavery depended on forced migration in order to provide means of socioeconomic expansion, while forced migration depended on the slave markets and the demand for slaves. The special feature of this dynamics was the religious element, which oriented these activities further and further away towards the pagans of Eastern Europe, the Caucasus, the Steppe the African South, while using transnational itineraries that spread throughout Central and Southern Europe, Mesopotamia, the trans-Sahara and the Mediterranean. Religion played an important role in the social and cultural integration of these migrants, since they were converted to the religion of their owners whether Christian, Muslim or Jewish as a means of social inclusion.

If we would like to draw some conclusions regarding the connection between forced migration and slavery, we need to look for the conditions which combined to generate a forced movement of people on a large scale in the medieval world. Firstly, we see that economic medieval expansion of the private as well as the public sectors depended on slavery. Secondly, social submission went together with integration of outsiders with no socioeconomic ties. Thirdly, the special religious aspect of the medieval Mediterranean world constituted religious outsiders as the most apt for expanding the household. All this encouraged human trafficking on a transnational scale.

It is a truism that society that depends on foreigners for its socioeconomic dynamics will encourage the reception of migrants. It is also clear that slavery and other extreme forms of social dependency are particularly encouraged by societies in which labor is a commodity. However, the transnational nexus of slavery in the medieval Mediterranean was aimed not so much towards the exploitation of the labor of forced migrants, but towards their integration into society in versatile ways. Foreign enslaved persons proved to be the most versatile. Slavery ensured their dependency as forced migrants while transnational forced migration ensured that their integration into the social fabric as freedmen would not disrupt the perpetuation of slavery. The fact that the demand for human merchandize came from the wealthiest medieval societies was used by the people of Eastern Europe, the Caucasus and Central Europe in 
order to profit from the trade of human merchandise, which for them was an abundant commodity. Forced migration was oriented in view of an economic disparity between wealthy economies which depended on the integration of migrants as slaves to increase their wealth, and much less developed economies for which human trafficking was the main means to acquire wealth.

An increasing interest in the situation of forced migrants today leads us to acknowledge the international economic framework of transnational movements of people. The analysis of the nexus of forced migration and slavery in the Middle Ages shows that human trafficking and transnational slavery were possible because they linked different transnational socioeconomic rationales.

\section{Bibliography}

\section{Primary Sources}

Agobardi Lugdunensis Opera omnia, ed. L. van Acker, Turnhout 1981.

Basilii Magni, "Homilia II: In Psalmum XIV", PG 29:277.

Cecaumeno, Raccomandazioni e consigli di un galantuomo, ed. M.D. Spadaro, Alessandria 1998.

Codex Theodosianus, ed. Theodor Mommsen, Berlin 1962.

Codex Justinianus, ed. Paul Krüger, Hildesheim 1997.

Cosmas Indicopleustes, Topographie chrétienne, ed. W. Wolska-Conus, Paris 1968.

Die Novellen des Kaiserin Eirene, ed. Ludwig Burgmann, in Fontes minores 4 (Forschungen zur Byzantinischen Rechtsgeschichte 7), Frankfurt A.M. 1981, pp. 1-33.

Ibn Hāāwkal, Kitāb Sūrat al-ard, ed. M. J. de Goeje, Leiden 1967.

Ibn Khordādhbeh, Kitāb al-Masālik wa'l-mamālik, ed. M.J. de Goeje, Leiden 1967.

Ibn Fadlān, Voyage chez les Bulgares de la Volga, trans. Marius Canard, Paris 1988.

Ibn Rosteh, Kitāb al-A'ā̄k an-Nafissa VII, ed. M.J. de Goeje, Leiden 1967.

John Cameniates, De expugnatione Thessalonicae, ed. Gertrud Böhlig, Berlin 1973.

Les Novelles de Léon le Sage, eds. P. Noailles/A. Dain, Paris 1944.

Leges Novellae ad Theodosianum pertinentes, ed. Paul M. Meyer, Berlin 1962.

Leges militares (version B), ed. E. Korzenszky, in I.D. Zepos, Jus Graecoromanum, vol. 2, Athens 1939 .

Le Diwan d'Abū Firās al-Hamdānī, poète arabe du $\mathrm{IV}^{e}$ siècle de l'Hégire ( $\mathrm{x}^{e}$ siècle de J.-C.), ed. Sami Dahan, 2. vols., Beirut 1944.

Peira in Jus Graecoromanum, ed. I.D. Zepos, vol. 4, Athens 1931.

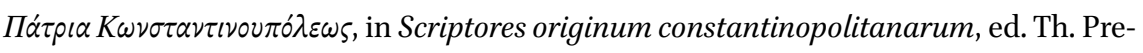
ger, vol. 2, Leipzig 1907.

Procopius Caesariensis, De bello Persico, ed. J. Haury, Leipzig 1962.

The Taktika of Leo VI, ed. and trans. G.T. Dennis, Washington D.C. 2010. 
Al-Tabarī, Ta'rīkh a-Rusul wa'l-Mulūk, ed. M.J. de Goeje, Leiden 1879-19o1.

Theophanes, Chronographia, ed. C. De Boor, 2 vols., Hildesheim 1963.

The Russian Primary Chronicle: Laurentian Text, trans. ed. S. Hazzard Cross/O.P. Sherbowitz-Wetzor, Cambridge, MA 1953.

The History of al-Tabari Vol. 36: The Revolt of the Zanj A.D. 869-879/A.H. 255-265, trans. David Waines, New York 1991.

Zhitie Nauma in Kirillo-metodies vskoj tradicii posle Kiralla i Mefodija, eds. B.N. Florja/A.A. Tarilov/S.A. Ivanon, St. Petersburg 2000.

\section{Secondary Literature}

Amitai, R./Cluse, Chr. (eds.), Slavery and the Slave Trade in the Eastern Mediterranean (c. 1000-1500 CE), Turnhout 2017.

Ashtor, E., “Aperçus sur les Radhanites”, Schweizerische Zeitschrift für Geschichte 27 (1977), 245-275.

Ashtor, E., "Gli Ebrei nel commercio mediterraneo nell'alto medioevo (sec. X-XI)", in Gli ebrei nell'alto medioevo. 30 marzo - 5 aprile 1978, Settimane di Studio del Centro Italiano di Studi sull'alto medioevo 26/1-2, vo. 1, Spoleto 1980, pp. 401-487.

Assaf, S., "Slavery and the Slave-Trade among the Jews during the Middle Ages (from the Jewish sources)", Zion 4 (1939-1940), 91-125 (in Hebrew).

Ayalon, D., Islam and the abode of war: Military slaves and Islamic adversaries, Aldershot, HA. 1994.

Bales, K., Disposable People: New Slavery in Global Economy, Berkeley 1999.

Bendall, S., "Slaves or Soldiers?", Nomismatika Chronika 8 (1989), 41-43.

Beševliev, V., Die protobulgarischen Inschriften, Berlin 1963.

Botte, R., "Les habits neufs de l'esclavage: métamorphoses de l'oppression au travail", Cahiers d'Études Africaines 45/3-4 (2005, Cahier 179-180 Esclavage moderne ou modernité de l'esclavage?), 651-666.

Botte, R. (ed.), L'ombre portée de l'esclavage : Avatars contemporains de l'oppression sociale, =Journal des africanistes 70/1-2 (2000).

Botte, R., Esclavages et abolitions en terres d'Islam: Tunisie, Arabie saoudite, Maroc, Mauritanie, Sudan, Brussels 2010.

Bradley, K., Slavery and Society at Rome, Cambridge 1994.

Buckland, W.W., The Roman Law of Slavery, Cambridge 1970.

Burdon, J., "Slavery as Punishment in Roman Criminal Law", in L.J. Archer (ed.), Slavery and other Forms of Unfree Labour, London 1988, pp. 68-85.

Cahen, C., "Y a-t-il eu des Radhanites ?" Revue des etudes juives 14/3 (1964), 499-505.

Campagnolo-Pothitou, M., "Les échanges de prisonniers entre Byzance et l'Islam aux IXe et Xe siècles", Journal of Oriental and African Studies 7 (1995), 1-55.

Canard, M., "Les sources arabes de l'histoire byzantine aux confins des X $\mathrm{X}^{\mathrm{e}}-\mathrm{XI}^{\mathrm{e}}$ siècles", Revue des études byzantines 19 (1961), 286-314 (repr. in idem, Byzance et les musulmans du Proche Orient, London 1973, pt. XVII). 
Canard, M., "La prise d'Héraclée et les relations entre Hârûn al-Rashîd et l'empereur

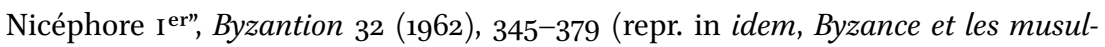
mans., pt. XVIII).

Castles, St., "Towards a Sociology of Forced Migration and Social Transformation", Sociology $37 / 1$ (2003), 13-34.

Christides, V., The conquest of Crete by the Arabs (ca. 824). A turning point in the struggle between Byzantium and Islam, Athens 1984.

Clancy, Sh.E., "Immigration and Modern Slavery: How the Laws of one fail to provide Justice to the Victims of the other", University of Baltimore Law Review 46/2 (2017), $335^{-}-35^{2}$.

Depatie-Pelletier, E., Judicial Review and Temporary Labour Migration Programs Declared a "Modern Form of Slavery": State Restrictions of (Im)Migrant Workers' Right to Liberty and Security (Not to Be Held Under Servitude) Through Employer-Tying Policies, Ph.D. dissertation, Montreal 2016.

Eltis, D., The Rise of Slavery in the Americas, Cambridge 2000.

Esperonnier, M., "Les échanges commerciaux entre le monde musulman et les pays slaves d'après les sources musulmanes médiévales", Cahiers de Civilisation Médiévale 23.1 (1980), 17-27.

Ferluga, J., "Der byzantinische Handel auf der Balkanhalbinsel vom vir. bis zum Anfang des XIII. Jahrhunderts", in Papers presented at the 5th International Congress of South-East European Research Studies held in Belgrad, nth-16th September, 1984, Skopje 1988, pp. 31-52, repr. in idem, Untersuchungen zur byzantinischen Provinzverwaltung. VI.-XIII.Jahrhundert, Amsterdam 1992, pp. 159-174.

Fiddian-Qasmiyeh, E./Loescher, G./Long, S./Sigona, N., The Oxford Handbook of Refugee and Forced Migration Studies, Oxford 2014.

Fontenay, M, "Corsaires de la foi ou rentiers du sol ? Les chevaliers de Malte dans le «corso» méditerranéen au XVII ${ }^{\mathrm{e}}$ siècle", Revue d'histoire moderne et contemporaine 35 (1988), 361-384.

Fontenay, M, "L’esclavage en Méditerranée occidentale au XVII ${ }^{\mathrm{e}}$ siècle", in La Méditerranée occidentale au XVII ${ }^{e}$ siècle, Paris 1990, pp. 11-50.

Franz, K., "Slavery in Islam: Legal Norms and Social Practice", in R. Amitai/Chr. Cluse (eds.), Slavery and the Slave Trade in the Eastern Mediterranean (c. 1000-1500 CE), Turnhout 2017, pp. 51-141.

Gieysztor, A., Les juifs et leurs activités économiques en Europe orientale, Paris 1980.

Gil, M., "The Radhanite Merchants and the Land of Radhan", Journal of the Economic and Social History of the Orient 17.3 (1974) 299-328.

Glancy, J.A., Slavery in Early Christianity, Oxford 2002.

Goitein, S.D., "Slaves and Slave girls in the Cairo Geniza Records", Arabica 9/1 (1962), 1-20.

Goitein, S.D., A Mediterranean Society: The Jewish Communities of the Arab World as portrayed in the Documents of the Cairo Genizah, 6 vols., Berkeley/Los Angeles 1967-1993. 
Goitein, S.D./Friedman, M.A., India traders of the middle ages: Documents from the Cairo Geniza, Leiden 2008.

Gordon, Murray, Slavery in the Arab World, New York 1998.

Gordon, Matthew, "Preliminary remarks on slaves and slave labor in the third/ninth century Abbasid Empire", in L. Culbertson (ed.), Slaves and Households in the Near East, Chicago 2011, pp. 71-84.

Gordon, Matthew, "Unhappy Offspring? Concubines and Their Sons in Early Abbasid Society", International Journal of Middle East Studies 49/1 (2017), 153-157.

Harper, K., Slavery in the late Roman World, AD 275-425, Cambridge 2011.

Hendy, M.F., Studies in the Byzantine Monetary Economy, c. 300-1450, Cambridge 1985.

Henning, J., "Gefangenfesseln im slavischen Siedlungsraum und der europäische Sklavenhandel im 6. bis 12. Jahrhundert”, Germania 70 (1992), 403-426.

Holman, S.R., The Hungry Are Dying. Beggars and Bishops in Roman Cappadocia, New York 2001.

Holo, J., Byzantine Jewry in the Mediterranean Economy, Cambridge 2009.

Jiwa, Sh., "From Slaves to Supporters The role of the Slavs in the Fatimid Mediterranean Empire in the Fourth/Tenth Century CE", The Institute of Ismaili Studies (http://iis .ac.uk/academic-article/slaves-supporters-role-slavs-fatimid-mediterranean -empire-fourthtenth-century-ce, retrieved 1/5/2017).

Kahane, H./Kahane, R., "Notes on the linguistic history of 'sclavus", in Studi in onore di Ettore Lo Gatto e Giovanni Maver, Rome 1962, pp. 345-36o.

Kaiser, W., "Friction profitable. L'économie de la rançon en Méditerranée occidentale (XVI ${ }^{\mathrm{e}}-\mathrm{XVII}{ }^{\mathrm{e}}$ siècles)", in S. Cavaciocchi (ed.) Ricchezza del mare. Ricchezza dal Mare, secc. XIII-XVIII, Florence 2006, vol. 2, pp. 689-701.

Kaiser, W. (ed.), Le Commerce des Captifs: les intermédiaires dans l'échange et le rachat des prisonniers en Méditerranée, XVe-XVIIIe siècle, Rome 2008.

Kaser, M., Das römische Privatrecht, vol. 1, Munich 1959.

Kazanski, M./Nercessian, A./Zuckermann, C. (eds.), Les Centres proto-urbains russes entre Scandinavie, Byzance et Orient, Paris 2000.

Kemp, A./Raijman, R., "Bringing in State Regulations, Private Brokers, and Local Employers: A Meso-Level Analysis of Labor Trafficking in Israel”, International Migration Review 48/3 (2014), 604-642.

Kolia-Dermitzaki, A., "Some Remarks on the Fate of Prisoners of War in Byzantium (Ninth-Tenth Centuries)", in G.H. Cipollone (ed.), La liberazione dei 'captivi' tra christianità e islam, Vatican City 2000, pp. 583-620.

Köpstein, H., "Zur Novelle des Alexios Komnenos zum Sklavenstatus (1095)", Actes du $x v^{e}$ Congrès International d'Études Byzantines (Athens, 1976), vol. 4, pp. 160-172.

Köpstein, H., "Zum Bedeutungswandel von SCLAVUS", Byzantinische Forschungen 7 (1979), 67-88.

Kulik, A., "Jews and the Language of Eastern Slavs", The Jewish Quarterly Review 104/1 (2014), 105-143. 
Lemerle, P., "Le Testament d'Eustathios Boïlas (avril 1059)", in P. Lemerle (ed.), Cinq Études sur le $x i^{e}$ s. byzantin, Paris 1977, pp. 15-63.

MacMaster, T., Slavery in the Early Middle Ages: A brief introduction with texts (https:// www.academia.edu/24341684/Slavery_in_the_Early_Middle_Ages_A_brief_intro duction_with_texts, retrieved on 1/2/2017).

Magee, R.V., "Slavery as Immigration?" University of San Francisco Law Review 44 (2009), 273-295.

Martin, B.G., "Medieval East Africa", Transactions of the Historical Society of Ghana 7 (1964), 124-131.

Martin, D.A./Aleinikoff, T.A./Motomura, H./Fullerton, M., Forced Migration: Law and Policy, Eagan MI 2007.

McCormick, M., Origins of the European Economy, AD 300-90o, Cambridge 2001.

Meillasoux, C., Anthropologie de l'esclavage: le ventre de fer et d'argent, Paris 1986.

Melluso, M., La schiavitù nell'età giustinianean, Besançon 2000.

Miers, S./Kopytoff, I. (eds.), Slavery in Africa: Historical and Anthropological Perspective, Madison 1977.

O'Connell Davidson, J., “Troubling freedom: migration, debt, and modern slavery”, $M i$ gration Studies 13 (2013), 1-20.

Oikonomides, N., "Silk Trade and Production in Byzantium", Dumbarton Oaks Papers 40 (1986), 33-53.

Quirk, J./Vigneswaran, D. (eds.), Migration and Contemporary Bondage in Africa, Trenton NJ 2013.

Pahlitzsch, J., "Slavery and the Slave Trade in Byzantium in the Palaeologan Period", in R. Amitai/Chr. Cluse (eds.), Slavery and the Slave Trade in the Eastern Mediterranean (c. 1000-1500 CE), Turnhout 2017, pp. 163-184.

Patlagean, E., "Nommer les Russes en Grec, 1081-1294", in S.W. Swierkosz-Lenart (ed.), Le origini e lo sviluppo della cristianità slavo-bizantina, Rome 1992, pp. 123-141.

Pelckmans, L, "Dependent Mobility of Domestic Workers of Slave Descent as Memoryscapes of Slavery in Urban Fulbe Families in Mali", in J. Quirk/D. Vigneswaran (eds.), Slavery, Migration and Contemporary Bondage in Africa, Trenton NJ 2013, pp. 149-180.

Perry, C.A., The Daily Life of Slaves and the Global Reach of Slavery in Medieval Egypt, 969-125o, Ph.D. dissertation, Atlanta: Emory University, 2014.

Pétré-Grenouilleau, O., Les traits négrières: Essais d'histoire globale, Paris 2004.

Rāgīb, Y., "Les esclaves publics aux premiers siècles de l'Islam”, in H. Bresc (ed.), Figures de l'esclave au Moyen Âge et dans le monde moderne, Paris 1996, pp. 7-30.

Rāgīb, Y., Actes de vente d'esclaves et d'animaux d'Egypte médiévale, 2 vols., Cairo 2002-2006.

Rio, A., "Freedom and Unfreedom in Early Medieval Francia: The Evidence of the Legal Formulae", Past \& Present 193 (2006), 7-40.

Rio, A., Slavery After Rome, 500-110o, Oxford 2017. 
Robinson, G., Cartulary of the Greek Monastery of St-Elias and St-Anastasius of Carbone, 3 vols., Rome 1928-1930.

Rotman, Y., "Formes de la non-liberté dans la campagne byzantine aux $\mathrm{VII}^{\mathrm{e}}-\mathrm{XI}^{\mathrm{e}}$ siècles", Mélanges de l'École Française de Rome, Moyen Âge 112/2 (2000), 499-510.

Rotman, Y., "Byzance face à l'Islam arabe viıe-Xe siècles", Annales H.S.S. 6o/4 (2005), $767-788$.

Rotman, Y., Byzantine Slavery and the Mediterranean World, trans. J.M. Todd, Cambridge 2009 .

Rotman, Y., "Captif ou esclave ? La compétition pour le marché d'esclaves en Méditerrané médiévale”, in F. Guillén/S. Trabelsi (eds.), Les Esclavages en Méditerranée et en Europe continentale. Espaces de traite et dynamiques économiques (Moyen Âge et Temps Modernes), Madrid 2012, pp. 25-46.

Rotman, Y., "Forms of Slavery", in P. Horden/Sh. Kinoshita (eds.), A Companion to Mediterranean History, Chichester 2014, pp. 263-278.

Rotman, Y., "Byzantium and the International Slave Trade in the Central Middle Ages", in Trade in Byzantium: Papers from the Third International Sevgi Gönül Byzantine Studies Symposium, Istanbul 2016, pp. 129-142.

Rotman, Y., "Comparing Slavery: History and Anthropology", in G. Stroumsa (ed.), Comparative Studies in the 21st Century - Prospects and Pitfalls, Jerusalem 2017.

Rudnyckyj, D., "Technologies of Servitude: Governmentality and Indonesian Transnational Labor Migration", Anthropological Quarterly $77 / 3$ (2004), 407-434.

Simeonova, L., "In the Depths of Tenth-Century Byzantine Ceremonial: the Treatment of Arab Prisoners-of-War at Imperial Banquets", Byzantine and Modern Greek Studies 22 (1998), 75-104.

Sophoulis, P., Byzantium and Bulgaria, 775-831, Leiden 2011.

Sorlin, I., "Les Traités de Byzance avec la Russie au $\mathrm{x}^{\mathrm{e}}$ siècle", Cahiers du Monde russe et soviétique $2 / 3-4$ (1961), 313-36o and 447-475.

Sorlin, I., "Voies commerciales, villes et peuplement de la Rôsia au $\mathrm{x}^{\mathrm{e}}$ siècle d'après le De administrando imperio de Constantin Porphyrogénète", in M. Kazanski/A. Nercessian/C. Zuckerman (eds.), Les Centres proto-urbains russes entre Scandinavie, Byzance et Orient, Paris 2000, pp. 337-356.

Stepputat, F./Nyberg Sørensen, N., "Sociology of Forced Migration", in E. FiddianQasmiyeh/G. Loescher/K. Long/N. Sigona (eds.), The Oxford Handbook of Refugee and Forced Migration Studies, Oxford 2014.

Tafel, G.L.F./Thomas, G.M., Urkunden zur Ältern Handels-und Staatsgeschichte der Republik Venedig, Amsterdam 1964.

Thomas, Y., "Vitae necisque potestas. Le père, la cité, la mort", in Du châtiment dans la cité. Supplices corporels et peine de mort dans le monde antique. Table ronde organisée par l'École française de Rome avec le concours du Centre national de la recherche scientifique (Rome 9-11 novembre, 1982), Rome 1984, pp. 499-548. 
Toch, M., The Economic History of European Jews. Late Antiquity and Early Middle Ages, Leiden 2013.

Turton, D., "Conceptualising forced migration", Refugee Studies Centre Working Paper Series 12 (2003) (https://www.rsc.ox.ac.uk/files/publications/working-paper-series/ wp12-conceptualising-forced-migration-2003.pdf, retrieved on 22/4/2017).

Vasiliev, A.A., Byzance et les Arabes, vol. 1, Brussels 1935.

Verlinden, Ch., "Les Radaniya : Intermédiaires commerciaux entre les mondes Germano-Slave et Gréco-Arabe", Graeco-Arabica 6 (1995), 111-124.

Ville, V., "Selling a Freeborn Child. Rhetoric and Social Realities in the Late Roman World", Ancient History 33 (2003), 169-207.

Watson, W.E., "Ibn al-Athīr's Accounts of the Rūs: A Commentary and Translation", Canadian-American Slavic Studies 35/4 (2001), 423-438.

Westbrook, R., "Vitae Necisque Potestas", Historia. Zeitschrift für alte Geschichte 48/2 (1999). 203-223. 